\title{
Trends in new particle formation in eastern Lapland, Finland: effect of decreasing sulfur emissions from Kola Peninsula
}

\author{
E.-M. Kyröô ${ }^{1}$ R. Väänänen ${ }^{1}$, V.-M. Kerminen ${ }^{1}$, A. Virkkula ${ }^{1,2}$, T. Petäjä ${ }^{1}$, A. Asmi ${ }^{1}$, M. Dal Maso ${ }^{3}$, T. Nieminen ${ }^{1}$, \\ S. Juhola ${ }^{4,5}$, A. Shcherbinin ${ }^{4}$, I. Riipinen ${ }^{6}$, K. Lehtipalo ${ }^{1,7}$, P. Keronen ${ }^{1}$, P. P. Aalto ${ }^{1}$, P. Hari ${ }^{8}$, and M. Kulmala ${ }^{1}$ \\ ${ }^{1}$ Department of Physics, University of Helsinki, Helsinki, Finland \\ ${ }^{2}$ Air Quality Research, Finnish Meteorological Institute, Helsinki, Finland \\ ${ }^{3}$ Department of Physics, Tampere University of Technology, Tampere, Finland \\ ${ }^{4}$ Department of Environmental Sciences, University of Helsinki, Helsinki, Finland \\ ${ }^{5}$ Department of Real Estate, Planning and Geoinformatics, Aalto University, Espoo, Finland \\ ${ }^{6}$ Department of Applied Environmental Science and Bert Bolin Centre for Climate Research, Stockholm University, \\ Stockholm, Sweden \\ ${ }^{7}$ Airmodus Oy, Pietari Kalmin katu 1 F 1, 00560 Helsinki, Finland \\ ${ }^{8}$ Department of Forest Sciences, University of Helsinki, Helsinki, Finland
}

Correspondence to: E.-M. Kyrö (ella-maria.kyro@helsinki.fi)

Received: 16 September 2013 - Published in Atmos. Chem. Phys. Discuss.: 26 November 2013

Revised: 31 March 2014 - Accepted: 3 April 2014 - Published: 5 May 2014

\begin{abstract}
The smelter industry in Kola Peninsula is the largest source of anthropogenic $\mathrm{SO}_{2}$ in the Arctic part of Europe and one of the largest within the Arctic domain. Due to socio-economic changes in Russia, the emissions have been decreasing especially since the late 1990 s resulting in decreased $\mathrm{SO}_{2}$ concentrations close to Kola in eastern Lapland, Finland. At the same time, the frequency of new particle formation days has been decreasing distinctively at SMEAR I station in eastern Lapland, especially during spring and autumn. We show that sulfur species, namely sulfur dioxide and sulfuric acid, have an important role in both new particle formation and subsequent growth and that the decrease in new particle formation days is a result of the reduction of sulfur emissions originating from Kola Peninsula. In addition to sulfur species, there are many other quantities, such as formation rate of aerosol particles, condensation sink and nucleation mode particle number concentration, which are related to the number of observed new particle formation (NPF) days and need to be addressed when linking sulfur emissions and NPF. We show that while most of these quantities exhibit statistically significant trends, the reduction in Kola sulfur emissions is the most obvious reason for the rapid decline in NPF days. Sulfuric acid explains approximately 20-50\% of the aerosol condensational growth observed at SMEAR I,
\end{abstract}

and there is a large seasonal variation with highest values obtained during spring and autumn. We found that (i) particles form earlier after sunrise during late winter and early spring due to high concentrations of $\mathrm{SO}_{2}$ and $\mathrm{H}_{2} \mathrm{SO}_{4}$; (ii) several events occurred during the absence of light, and they were connected to higher than average concentrations of $\mathrm{SO}_{2}$; and (iii) high $\mathrm{SO}_{2}$ concentrations could advance the onset of nucleation by several hours. Moreover, air masses coming over Kola Peninsula seemed to favour new particle formation.

\section{Introduction}

Both sulfur and primary particle emissions have been decreasing largely all over Europe (Kupiainen and Klimont, 2006; Vestreng et al., 2007; Smith et al., 2011), resulting in improved air quality, decreased acid fallout (Berge et al., 1999) and weakened direct radiative forcing by aerosols (Liepert and Tegen, 2002). The changes in indirect radiative forcing are more uncertain and complicated to address because the resulting decrease in $\mathrm{CCN}$ (cloud condensing nuclei) concentrations due to the decrease in primary particle emissions can be at least partly compensated by secondary CCN production (new particle formation and growth) 
(Hamed et al., 2010; Makkonen et al., 2012). In the future, larger natural emissions of natural aerosol precursors due to warmer temperatures are likely to assist $\mathrm{CCN}$ production further (Makkonen et al., 2012; Paasonen et al., 2013).

The smelter industry in Kola Peninsula is not only the most important source of anthropogenic atmospheric $\mathrm{SO}_{2}$ in the Finnish eastern Lapland but also the largest or second largest source in the entire Arctic domain (Benkovitz et al., 1996; Prank et al., 2010), depending on the definition of the Arctic boundaries. During the past 2 decades, sulfur emissions from the Kola area have decreased distinctively, although they are still larger than those of entire Finland (Paatero et al., 2008). The SMEAR I station (Station for Measuring EcosystemAtmosphere Relations) (Hari et al., 1994) was established in 1991 to measure the impact of Kola sulfur emissions on the forests in eastern Lapland. The station is located only $6 \mathrm{~km}$ from the Russian boarder (Fig. 1a). Värriö Subarctic Research Station is located about $800 \mathrm{~m}$ south of SMEAR I.

New particle formation (NPF) is tightly linked with $\mathrm{SO}_{2}$ : when in the atmosphere, $\mathrm{SO}_{2}$ is oxidized to sulfuric acid $\mathrm{H}_{2} \mathrm{SO}_{4}$, which in turn is known to be the most important chemical component in new particle formation (Kulmala et al., 2004a; Sipilä et al., 2010; Kerminen et al., 2010). In the boreal forest zone, organic compounds are connected to new particle formation and growth (Kulmala et al., 2004b; Tunved et al., 2006; Paasonen et al., 2010). On the other hand, low values of condensation sink (CS), a measure of the ability of pre-existing aerosol particles to uptake condensable vapours (Kulmala et al., 2001), increase the probability of new particle formation. Thus, decreasing $\mathrm{SO}_{2}$ concentrations decrease the probability of NPF by decreasing $\mathrm{H}_{2} \mathrm{SO}_{4}$ concentrations while at the same time decreasing values of CS caused by smaller sulfur, and primary particle emissions tend to increase this probability.

Our main goal in this manuscript is find out whether NPF characteristics show any changes in eastern Lapland over the last 14 years and, if they do, whether there is any connection between their trends and the change in Kola emissions. More specifically, we aim to address the following questions: (1) is the signature from decreased Kola emissions observable in NPF characteristics and associated trends?, (2) what are the relative roles of the decreasing $\mathrm{SO}_{2}$ concentration and decreasing value of condensation sink on NPF?, (3) how do changes in primary particle emissions, NPF and subsequent aerosol growth influence cloud condensation nuclei concentrations?, and (4) how does the situation in eastern Lapland differ from that reported for western Lapland where the influence of Kola is expected to be much smaller. We will present long-term time series of $\mathrm{SO}_{2}$ and aerosol particle number concentrations, NPF characteristics, as well as various other quantities related to NPF. We will also investigate how the seasonal distributions of these quantities have changed over the time and analyse the effect of air mass routes to NPF.

\section{Materials and methods}

The SMEAR I station $\left(67^{\circ} 45^{\prime} 31^{\circ} \mathrm{N}, 29^{\circ} 36^{\prime} 41^{\circ}\right.$ E) (Fig. 1b) is built on the top of Kotovaara hill, $390 \mathrm{~m}$ a.s.l. The station is surrounded by a 60-year-old Scots pine (Pinus sylvestris) forest (Fig. 1c) and is located at the north side of the Värriö fell range, with peaks reaching from 500 to $550 \mathrm{~m}$ a.s.l. The highest fjeld north of SMEAR I is Nuortti (482 m a.s.l., furthermost snow-covered fjeld in Fig. 1c). Most of the area is dominated by Scots pine forests, in addition to which there are also large wetlands and deep gorges in the surroundings. The infrastructure of SMEAR I includes a small hut for the aerosol analysers and gas analysers (Fig. 1b) and a $16 \mathrm{~m}$ high weather mast. Some instruments have housings outside and also continuous chamber measurements of photosynthesis from the surrounding trees area conducted.

In this paper, we will use measurements of the aerosol number size distributions, $\mathrm{SO}_{2}$ concentrations and meteorological variables. The aerosol size distribution is measured with a differential mobility particle sizer (DMPS), which classifies the particles according to their electrical mobility (related to particle diameter) (Aalto et al., 2001). The DMPS was installed to SMEAR I in autumn 1997, and the cut-off diameter was changed from $8 \mathrm{~nm}$ to $3 \mathrm{~nm}$ in 2005. $\mathrm{SO}_{2}$ has been measured since autumn 1991 with a pulsed fluorescence analyser.

The days were classified into event, non-event and undefined days visually by looking at the daily aerosol size distributions. During an event day a new, growing mode appears below $25 \mathrm{~nm}$ (Dal Maso et al., 2005; Kulmala et al., 2012). During a non-event day there is no new mode below $25 \mathrm{~nm}$, whereas during an undefined day (although there is a new sub- $25 \mathrm{~nm}$ mode) it does not grow. The event days were further classified into classes I and II according to whether there was strong fluctuations in the mode concentration or diameter (class II) or not (class I).

As a proxy for gaseous sulfuric acid concentrations, two parameterizations exist (Petäjä et al., 2009; Mikkonen et al., 2011). In this study we used both. The first proxy is a linear parameterization developed by Petäjä et al., (2009) for a boreal SMEAR II site in central Finland:

$\left[\mathrm{H}_{2} \mathrm{SO}_{4}\right]_{\mathrm{P}}=\frac{k_{3} \cdot \mathrm{SO}_{2} \cdot \mathrm{Rad}}{\mathrm{CS}}$,

where $k_{3}$ is a fitting parameter, $\mathrm{SO}_{2}$ the sulfuric dioxide concentration, Rad the radiation and CS the condensation sink. While either global or UV-B radiation can be used in calculating the proxy, we used global radiation due to better data availability. The proxy given by Eq. (1) is physically well based, yet it is expected to be slightly inaccurate in environments where the value of CS is very low. This is because the pseudo-steady sulfuric acid concentration assumed by this proxy is achieved over the timescale $\mathrm{CS}^{-1}$. In case of Värriö, this means that the proxy tends to overestimate sulfuric acid concentrations before the local noon and underestimate 


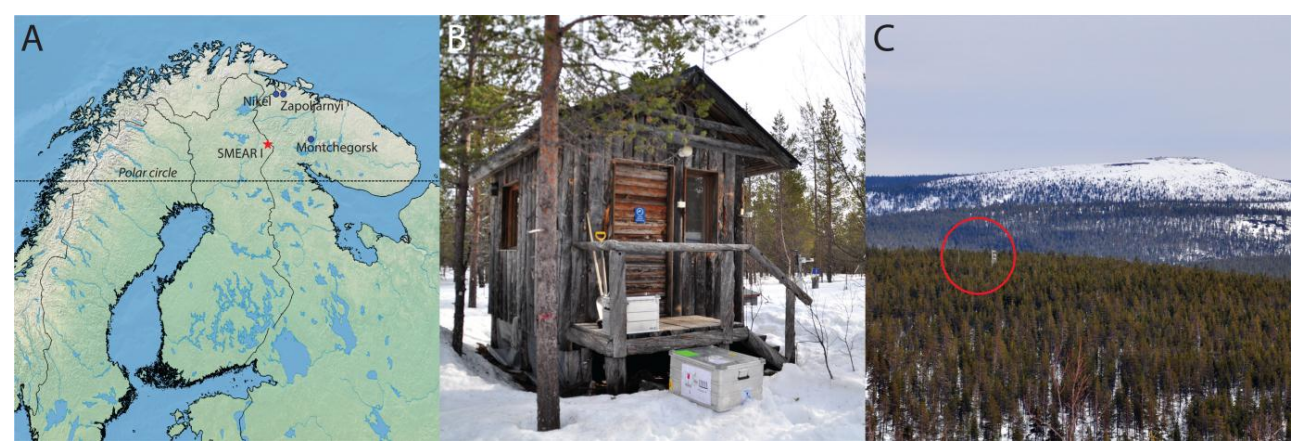

Fig. 1. Location of SMEAR I (Värriö) station and three major mining cities in the Kola Peninsula (A). The polar circle is also shown on the map. A photo of SMEAR I station (B) and an aerial photo of the surroundings (C). The location of SMEAR I is circled with red.

them in the afternoon. The second proxy for $\mathrm{H}_{2} \mathrm{SO}_{4}$ we used was a non-linear statistical proxy, developed by Mikkonen et al. (2011):

$$
\begin{aligned}
{\left[\mathrm{H}_{2} \mathrm{SO}_{4}\right]_{\mathrm{M}} } & =8.21 \times 10^{-3} \cdot k \cdot \mathrm{Rad} \cdot\left[\mathrm{SO}_{2}\right]^{0.62} \\
& \cdot(\mathrm{CS} \cdot \mathrm{RH})^{-0.13},
\end{aligned}
$$

where $k$ is a non-linear function of both temperature and atmospheric pressure and RH is the relative humidity. In this proxy, the role of CS is less important. The validity of the proxy given by Eq. (2) has not been tested for conditions typical for Värriö, so we apply it mainly as a tool to investigate the sensitivity of our results to the uncertainty in gaseous sulfuric acid concentration.

The trends of various parameters were calculated in the least-squares sense by fitting to logarithms of the measured and calculated data. These trends were then fitted to data model with a logarithmic trend component (relative trend) and four-component stationary sinusoidal seasonal signal:

$$
\begin{aligned}
\log (x)= & a+b t+s_{1} \sin \left(\frac{2 \pi t}{1 \mathrm{yr}}\right)+s_{2} \sin \left(\frac{4 \pi t}{1 \mathrm{yr}}\right) \\
& +s_{3} \cos \left(\frac{2 \pi t}{1 \mathrm{yr}}\right)+s_{1} \cos \left(\frac{4 \pi t}{1 \mathrm{yr}}\right)+S,
\end{aligned}
$$

where $x$ is the fitted parameter, $a$ a constant factor, $b$ the logarithmic trend, $s_{1}$ to $s_{4}$ seasonal signal parameters, and $S$ the residual noise term. In practice, the minimization of Eq. (3) in the least-squares sense was obtained with Matlab routine lscov (Mathworks, Inc., 2010). In addition to this, we also used Mann-Kendall (Mann, 1945; Kendall, 1975) trend test for estimating the trends and their significance. Sample autocorrelation was not taken into account in any of the fitting procedures.

Finally, we used HYSPLIT back trajectories (Draxler and Hess, 1998) as a tool to investigate how frequently the air masses arriving at Värriö had been over Kola during the event days. We calculated the percentage of time that the air masses had spent over Kola before arriving at Värriö for each month, during the whole time period 1998-2011 and during the event days only. In order to be classified as arriving over Kola, the trajectory had to stay over the defined Kola area more than $50 \%$ or $80 \%$ of the last $36 \mathrm{~h}$ before arriving at Värriö.

\section{Results and discussion}

\subsection{Overview of new particle formation and growth in Värriö}

\subsubsection{General characteristics of new particle formation events}

On average, $15 \%$ of the days were event days during the time period 1998-2011. The average growth rate (GR) of particles during the event days was $2.7 \mathrm{~nm} \mathrm{~h}^{-1}$, and the corresponding formation rate of $8 \mathrm{~nm}$-sized particles was $0.15 \mathrm{~cm}^{-3} \mathrm{~s}^{-1}$. The mean formation rate of $3 \mathrm{~nm}$-sized particles (20052011) was $0.24 \mathrm{~cm}^{-3} \mathrm{~s}^{-1}$. There was a clear seasonal pattern in GR, the highest values being both during summer but almost as high also during winter (Table 1). On average, the highest values of $J_{3}$ were reached during AprilMay, whereas $J_{8}$ peaked already earlier, in February-April (Table 1). On average, there were 54 events per year, out of which 20 were class I events for which it was possible to determine both growth and formation rates. The event fraction had a bimodal yearly distribution with the maximum in the spring (March-April-May, 0.26-0.28) and another local maximum in the autumn (September, $\sim 0.22$ ) (Fig. 2a). The non-event fraction on the other hand was highest in the winter (October-February, $\sim 0.6-0.8$ month $^{-1}$ ) (Fig. 2b). The undefined day fraction peaked in April $(\sim 0.4)$ and had a minimum in December ( $\sim 0.12)$ (Fig. $2 c)$.

The events started on average about $7 \mathrm{~h}$ after the sunrise, but some events started when the sun was below the horizon (Fig. 3). On average these events were associated with twice as high $\mathrm{SO}_{2}$ concentrations as during event days in general. Compared to other seasons, there was larger variation in the start times in spring, and the average event start time was 

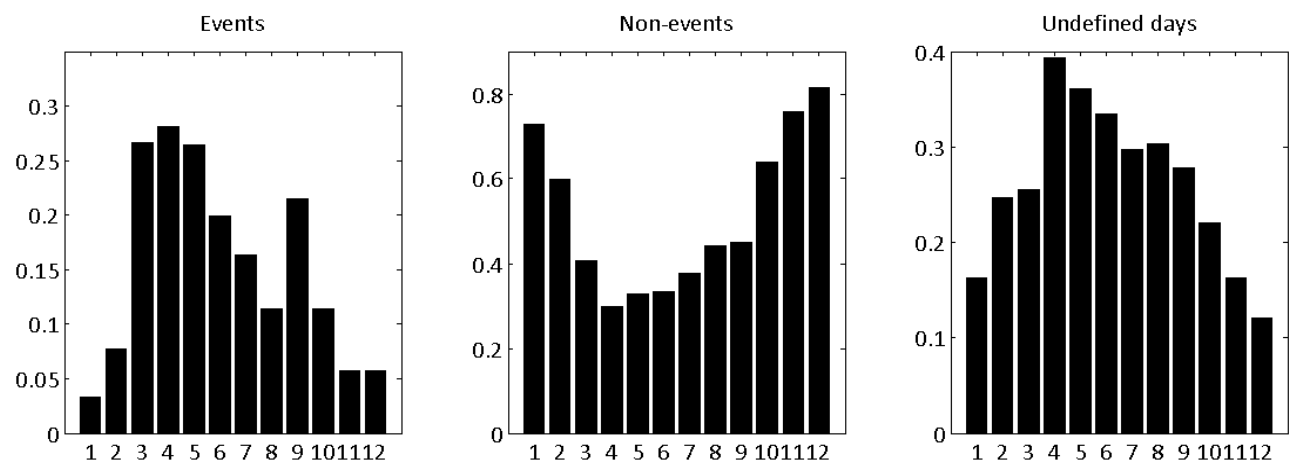

Fig. 2. Mean monthly event, non-event and undefined day fraction 1998-2011.

Table 1. Monthly mean values (bold) for GR (1992-2011), $J_{8}$ (1992-2011) and $J_{3}(2005-2011)$. The monthly 25 th and 75 th percentiles are shown below the means, respectively.

\begin{tabular}{lcccccccccccc}
\hline & Jan & Feb & Mar & Apr & May & Jun & Jul & Aug & Sep & Oct & Nov & Dec \\
\hline $\mathrm{GR}_{\left(\mathrm{nm} \mathrm{h}^{-1}\right)}$ & $\mathbf{3 . 1}$ & $\mathbf{3 . 5}$ & $\mathbf{2 . 1}$ & $\mathbf{1 . 8}$ & $\mathbf{2 . 5}$ & $\mathbf{3 . 8}$ & $\mathbf{4 . 4}$ & $\mathbf{3 . 7}$ & $\mathbf{2 . 8}$ & $\mathbf{2 . 2}$ & $\mathbf{2 . 9}$ & $\mathbf{2 . 1}$ \\
& 1.8 & 2.4 & 1.1 & 1.1 & 1.2 & 2.6 & 3.2 & 2.9 & 2.2 & 1.6 & 2.3 & 1.2 \\
& 2.9 & 4.1 & 2.9 & 2.4 & 3.6 & 4.7 & 4.7 & 4.3 & 3.2 & 2.6 & 2.9 & 2.3 \\
\hline$J_{8}$ & $\mathbf{0 . 0 5}$ & $\mathbf{0 . 1 9}$ & $\mathbf{0 . 2 0}$ & $\mathbf{0 . 2 1}$ & $\mathbf{0 . 1 6}$ & $\mathbf{0 . 1 3}$ & $\mathbf{0 . 1 7}$ & $\mathbf{0 . 1 1}$ & $\mathbf{0 . 1 2}$ & $\mathbf{0 . 0 8}$ & $\mathbf{0 . 1 1}$ & $\mathbf{0 . 0 4}$ \\
$\left(\mathrm{cm}^{-3} \mathrm{~s}^{-1}\right)$ & 0.02 & 0.04 & 0.04 & 0.05 & 0.05 & 0.06 & 0.07 & 0.06 & 0.06 & 0.03 & 0.05 & 0.02 \\
& 0.07 & 0.24 & 0.16 & 0.22 & 0.23 & 0.13 & 0.23 & 0.15 & 0.14 & 0.13 & 0.17 & 0.06 \\
\hline$J_{3}$ & $\mathbf{0 . 0 7}$ & $\mathbf{0 . 1 1}$ & $\mathbf{0 . 1 7}$ & $\mathbf{0 . 4 5}$ & $\mathbf{0 . 3 2}$ & $\mathbf{0 . 1 6}$ & $\mathbf{0 . 2 3}$ & $\mathbf{0 . 1 9}$ & $\mathbf{0 . 1 8}$ & $\mathbf{0 . 1 3}$ & $\mathbf{0 . 0 9}$ & $\mathbf{0 . 0 4}$ \\
$\left(\mathrm{cm}^{-3} \mathrm{~s}^{-1}\right)$ & 0.07 & 0.03 & 0.07 & 0.13 & 0.07 & 0.12 & 0.10 & 0.07 & 0.06 & 0.04 & 0.07 & 0.02 \\
& 0.07 & 0.20 & 0.19 & 0.41 & 0.26 & 0.24 & 0.33 & 0.31 & 0.30 & 0.20 & 0.12 & 0.06 \\
\hline
\end{tabular}

earlier. This suggests that during spring the amount of sulfuric acid that is needed to trigger the NPF is reached earlier during the day than in other seasons. The sulfuric acid concentrations are, in fact, likely to be elevated in Värriö during spring (Fig. 4) as a result of high $\mathrm{SO}_{2}$ and low CS.

It is of interest to compare the results from Värriö to those from Pallas in western Lapland. Both stations are located at the northernmost edge of the boreal region, but while Värriö is close to the sulfur pollution sources in Kola Peninsula, Pallas is far away from any anthropogenic sulfur pollution sources. The NPF event frequency in Pallas is generally slightly lower than in Värriö (Asmi et al., 2011). In addition, the annual event frequency distribution in Pallas is unimodal, with a peak in April and then gradually decreasing towards autumn (Asmi et al., 2011). In Pallas, the fraction of undefined days is on average about 0.14 month $^{-1}$ lower, and the number of non-events is on average 0.26 month $^{-1}$ greater than in Värriö, but the yearly distributions from both sites resemble each other. The observed average values of GR and $J$ are well in line with the previous studies from Finnish Lapland (Komppula et al., 2003; Dal Maso et al., 2007; Asmi et al., 2011), and slightly smaller than the corresponding values observed at SMEAR II, southern Finland (Dal Maso et al., 2007; Nieminen et al., 2014). A similar seasonal behaviour of GR has been observed earlier in Värriö (Dal Maso et al., 2007), but in Pallas only summer maximum is seen (Asmi et al., 2011). The earlier onset of nucleation during spring has not been observed earlier in northern Finland (Vehkamäki et al., 2004; Asmi et al., 2011). Vehkamäki et al. (2004) used the time when elevated concentrations of $8 \mathrm{~nm}$ particles were first observed, as the event start time, which shifts the spring event start times later since the growth rates are at their minimum in spring. We, in turn, estimated the formation time of $1.5 \mathrm{~nm}$ clusters assuming a constant GR below the cut-off size of DMPS. Since particle growth rates tend to increase with an increasing particle size in the sub-5-10 nm diameter size range (Hirsikko et al., 2005; Yli-Juuti et al., 2011; Kuang et al., 2012; Kulmala et al., 2013), the real starting times of the events might even be earlier than estimated here.

From March to July, the CS during event days was on average $67 \%$ of the non-event day value. This is mostly a result of much lower accumulation mode concentrations during the event days. Also, the mean sulfuric acid proxy was $30 \%$ higher during event days than during non-event days. Similar behaviour is also observed elsewhere in the boreal region (Petäjä et al., 2009). Also the global radiation was $60 \%$ higher during event days than during non-event days. Contrary to the observations from Pallas in western 

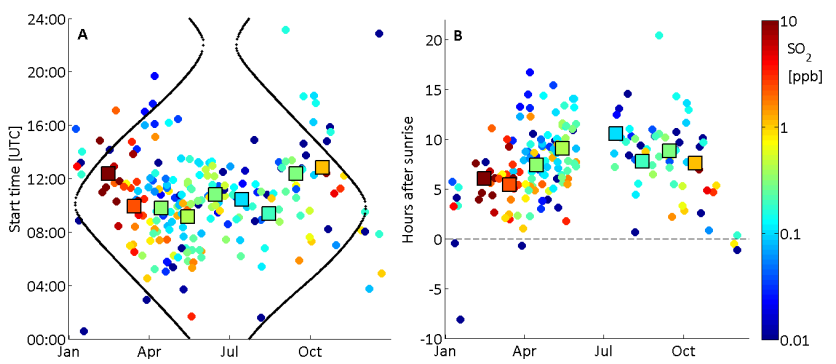

Fig. 3. New particle formation event start times as UTC (A) and hours after sunrise $(\mathbf{B})$ at $1.5 \mathrm{~nm}$ as a function of $\mathrm{SO}_{2}$ concentration (colour scale) for each event separately (circles). The filled rectangles represent the monthly averages for months with at least 10 events. The black curves in (A) denote the sunrise and sunset times, respectively.

Lapland or Hyytiälä in southern Finland, sulfur dioxide on average increased early during the event day mornings reaching above $0.9 \mathrm{ppm}$ and levelling to around $0.6 \mathrm{ppb}$ in the evening, while during non-event days there was not as much daily variation and the concentrations were generally around $0.2 \mathrm{ppb}$ lower. During the events observed during dark time (global radiation $<20 \mathrm{~W} \mathrm{~m}^{-3}$ ), the $\mathrm{SO}_{2}$ concentration was on average two times higher than on an average event day. Also, lower temperatures seemed to favour new particle formation.

\subsubsection{Trends in event characteristics and associated aerosol properties}

When looking at the yearly number of event, non-event and undefined days, the new particle formation days have been decreasing by $3.7 \% \mathrm{yr}^{-1}$ (Table 2). Moreover, there has been a radical decrease in class I event days $\left(-9.9 \% \mathrm{yr}^{-1}\right)$ (Fig. 5a, Table 2), and a more subtle increase in the nonevents $\left(+3.1 \% \mathrm{yr}^{-1}\right)$ (Fig. 5b, Table 2). However, there was no trend in the class II events or in the undefined days (Table 2). If the class I events are divided further into class Ia, including very clear and undisturbed events, and class Ib, including the rest of the class I events, the decrease was most pronounced in the class Ia cases $\left(-16.7 \% \mathrm{yr}^{-1}\right)$ (Table 2). During the last 4 years of this data set, these events have been observed only during 1 year (2010). At Pallas, such a trend in NPF days was not observed (Asmi et al., 2011).

When the data are divided into two equally long periods, 1998-2004 and 2005-2011, the seasonal NPF distribution changed markedly, especially in the case of class I events (Fig. 6a-b). In the first period the distribution was clearly bimodal, with a strong maximum in the spring and another smaller maximum in the autumn. In the later period the events were more evenly distributed and the autumn maximum had disappeared from both class I and II events (Fig. 6a-b). The decrease in the number of events is most pronounced in spring and autumn. In fact, the distribution of the latter period resembles more the one observed at Pal- las (Asmi et al., 2011). The non-event days have increased throughout the year with largest increase during summer and autumn. The number of undefined days on the other hand has increased during late spring and decreased during late winter (Fig. 6c-d). The average number of class I events in Pallas is about $6 \mathrm{yr}^{-1}$ (Asmi et al., 2011), which is close to the number of class I events observed in Värriö in the end of the time series. This could be an indication that previously the class I events that were observed in Värriö have been the result of both natural background as well as the extra boost from Kola emissions. The number of class II events, on the other hand, did not change that much, but the seasonal distribution somewhat smoothened. Since class II events are not usually observed to start from the smallest size classes, we also hypothesize that the observation of class II event is connected to the amount of organic vapours rather than sulfur emissions from Kola since the contribution of organics to growth increases with increasing particle size (Riccobono et al., 2012; Riipinen et al., 2012).

Over the time period considered here, there was no significant trend in GR (Fig. 7a, Table 2), although in Hyytiälä there appears to be a significant positive trend (Nieminen et al., 2013, 2014). In Pallas high values of GR seem to be connected to high NPF event frequency (Asmi et al., 2011), but this was not seen Värriö. In the apparent formation rate of $8 \mathrm{~nm}$ particles, on the other hand, there was no significant trend. For 2005-2011 the trend in $J_{8}$ was very similar with both methods, $-10.0 \% \mathrm{yr}^{-1}$ using the least-squares method and $-10.2 \% \mathrm{yr}^{-1}$ using the Mann-Kendall method ( $P=0.06$ ) (Fig. 7b, Table 2). For the apparent formation rate of $3 \mathrm{~nm}$ particles, the trend was not significant. However, during $2005 J_{3}$ could be determined only from eight events, all of which were concentrated to April-June, when $J_{3}$ usually has the highest values. For years 2006-2011 the trend was significant and positive (Table 2).

The nucleation mode particle number concentration has increased about $4.3 \% \mathrm{yr}^{-1}$ (Fig. 8a, Table 2), whereas the total aerosol number concentration has decreased by $2.5 \% \mathrm{yr}^{-1}$ (Fig. 8b, Table 2). The decrease in the condensation sink (CS) is even larger, $7.7 \% \mathrm{yr}^{-1}$ (Fig. 8c, Table 2). The trends are very similar also when using the MannKendall method (Table 2).

While decreasing sulfur emissions decrease the $\mathrm{H}_{2} \mathrm{SO}_{4}$ concentration and hence nucleation and growth, on the other hand it also leads to a decrease in primary emissions and hence decrease in the condensation and coagulation sinks. When CS decreases, more condensable vapours are left to the atmosphere, which can form new particles instead of condensing into pre-existing particles. Since the NPF event frequency is decreasing in Värriö, each NPF event must produce more particles than before as nucleation mode particle concentration is increasing. This can be seen in the increase of event time $J_{3}$ (Table 2). However, since there was no significant trend in the apparent formation rate of $8 \mathrm{~nm}$ particles ( $J_{8}$, Table 2 ), the particle production must have increased 

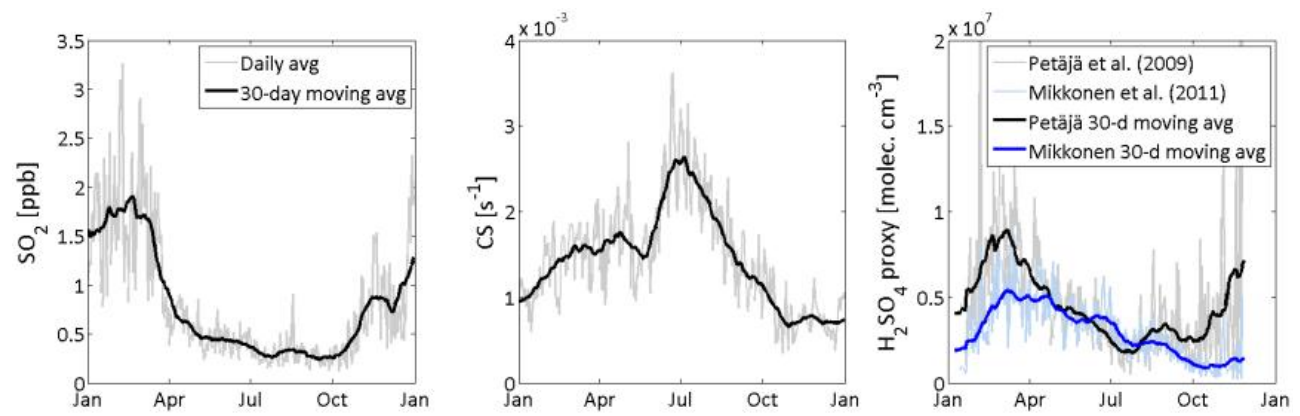

Fig. 4. The seasonal pattern of $\mathrm{SO}_{2}, \mathrm{CS}$ and $\mathrm{H}_{2} \mathrm{SO}_{4}$ proxy, average of years 1992-2011.
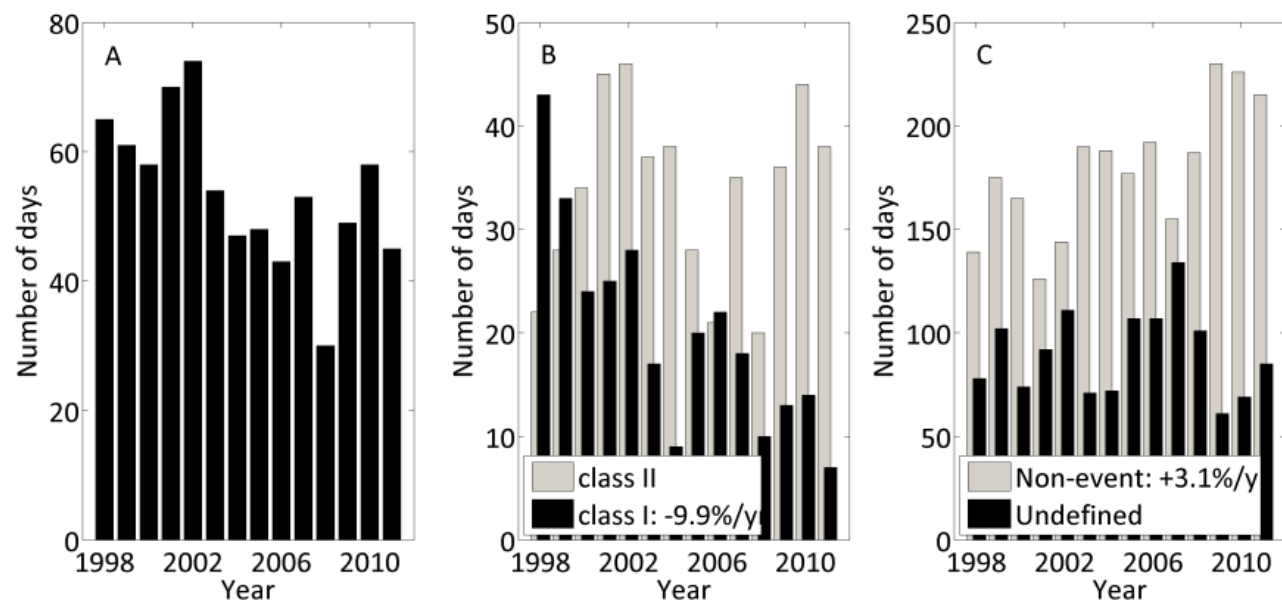

Fig. 5. Yearly number of event days (A), divided into classes I and II (B) and yearly number of undefined and non-event days (C).
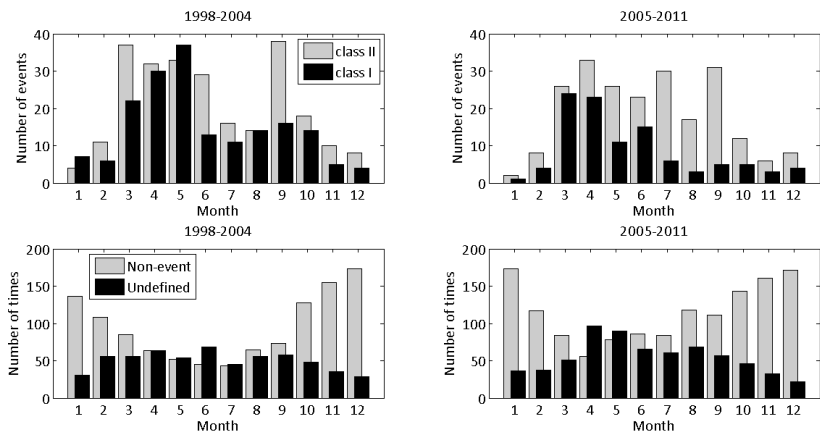

Fig. 6. The seasonal distribution of events, non-events and undefined days during 1998-2004 (leftmost panels) and 2005-2011 (rightmost panels).

only in the smallest particle sizes. It is also possible that some of the increase in nucleation mode comes from an increased apparent particle production in the highest end of nucleation mode during class II events or undefined days. Contrary to our findings, Hamed et al. (2010) reported a clear decrease in $J_{3}$, as a result of reduced sulfur emissions and thus decreased number of nucleation days in eastern Germany but on the other hand an increase in the subsequent growth of aerosol particles. Both $\mathrm{SO}_{2}$ and organic compounds contribute to the value of $J_{3}$, and the importance of extremely low-volatile organic compounds (ELVOCs) is likely to be much higher in the boreal region (Ehn et al., 2014) than elsewhere and even higher in the pristine areas in the northern edge of the boreal zone.

\subsubsection{From formation to growth: trends in cloud condensation nuclei concentrations}

In order to have climatic relevance, newly formed aerosol particles need to grow to sufficiently large sizes. In moderately polluted environments, such as boreal forests, aerosol particles may act as cloud condensation nuclei (CCN) after reaching diameters between about 50 and $150 \mathrm{~nm}$ (Kerminen et al., 2005; Komppula et al., 2005; Sihto et al., 2011). Other sources for atmospheric CCN are primary emissions of $\mathrm{CCN}$ active particles and atmospheric aging (e.g. condensation growth or increase of hygroscopicity) of originally nonCCN active primary particles (Pierce and Adams, 2009; Kerminen et al., 2012).

We made linear fits to the logarithms of $\mathrm{CN}_{50}, \mathrm{CN}_{80}$, $\mathrm{CN}_{100}$ and $\mathrm{CN}_{150}$ (particles larger than 50, 80, 100 and 
Table 2. Trends for various parameters obtained using both least-squares covariance method where the seasonal trend has been taken into account, as well as Mann-Kendall method (Sen's slope) without seasonality, as percentages per year. The slopes are for years 1998-2011, unless mentioned otherwise. The lower and upper 95th confidence intervals for Sen's slopes are given for significant trends $(P<0.05)$, except for $J_{8}$ (2005-2011) where the confidence intervals are given in parentheses, although $P=0.062$.

\begin{tabular}{lrrrrr}
\hline Parameter & $\begin{array}{r}\text { Slope (least- } \\
\text { squares cov. } \\
{\left[\% \mathrm{yr}^{-1}\right]}\end{array}$ & $\begin{array}{r}\text { Sen's slope } \\
{\left[\% \mathrm{yr}^{-1}\right]}\end{array}$ & $\begin{array}{r}\text { Lower conf. } \\
\text { interval for Sen's } \\
\text { slope }\left[\% \mathrm{yr}^{-1}\right]\end{array}$ & $\begin{array}{r}\text { Upper conf. } \\
\text { interval for Sen's } \\
\text { slope }\left[\% \mathrm{yr}^{-1}\right]\end{array}$ & $P$ \\
\hline $\mathrm{SO}_{2}(1992-2011)$ & -5.2 & -4.8 & -5.5 & -4.1 & $<0.001$ \\
$\mathrm{SO}_{2}$ & -10.9 & -11.3 & -12.4 & -10.2 & $<0.001$ \\
$\mathrm{H}_{2} \mathrm{SO}_{4}$ Petäjä & -5.2 & -6.2 & -7.5 & -4.9 & $<0.001$ \\
$\mathrm{H}_{2} \mathrm{SO}_{4}$ Mikkonen & -8.0 & -8.6 & -9.5 & -7.7 & $<0.001$ \\
Nucleation mode & 4.3 & 3.7 & 2.7 & 4.7 & $<0.001$ \\
Total conc. & -2.5 & -2.4 & -3.0 & -1.7 & $<0.001$ \\
$\mathrm{CN}>50 \mathrm{~nm}$ & -3.9 & -3.9 & -4.6 & -3.1 & $<0.001$ \\
$\mathrm{CN}>80 \mathrm{~nm}$ & -4.1 & -4.2 & -4.9 & -3.5 & $<0.001$ \\
$\mathrm{CN}>100 \mathrm{~nm}$ & -3.9 & -4.0 & -4.7 & -3.3 & $<0.001$ \\
$\mathrm{CN}>150 \mathrm{~nm}$ & -3.2 & -3.3 & -4.0 & -2.6 & $<0.001$ \\
$\mathrm{CS}$ & -7.7 & -8.0 & -8.7 & -7.4 & $<0.001$ \\
Temperature & 0.05 & 0.04 & 0.02 & 0.07 & 0.001 \\
$\mathrm{GR}$ & 1.5 & -0.2 & & & 0.803 \\
$J_{3}(2005-2011)$ & 8.4 & 9.6 & & & 0.093 \\
$J_{3}(2006-2011)$ & 26.2 & 29.7 & 15.5 & 42.2 & $<0.001$ \\
$J_{8}$ & -1.3 & -1.0 & & & 0.496 \\
$J_{8}(1998-2004)$ & 2.2 & 3.0 & & & 0.519 \\
$J_{8}(2005-2011)$ & -10.0 & -10.2 & $(-18.7)$ & $( \pm 0.0)$ & 0.062 \\
Event class I & & -9.9 & -14.2 & -5.9 & 0.002 \\
Event class Ia & & -16.7 & -24.4 & -10.6 & $<0.001$ \\
Event class Ib & & -8.1 & -13.6 & -2.6 & 0.002 \\
Event class II & & 1.1 & & & 0.661 \\
All events & & -3.7 & -5.7 & -0.5 & 0.025 \\
Undefined & & -0.6 & & & 0.701 \\
Non-events & & 3.1 & 1.2 & 5.1 & 0.009 \\
\hline
\end{tabular}

$150 \mathrm{~nm}$, respectively) concentrations. All of them showed a statistically significant decreasing trend over the study period (Table 2). The largest decrease was seen for particles larger than $80 \mathrm{~nm}\left(-4.1 \% \mathrm{yr}^{-1}\right)$, and the lowest one for particles larger than $150 \mathrm{~nm}\left(-3.2 \% \mathrm{yr}^{-1}\right)$ (Fig. 9, Table 2). Both $\mathrm{CN}_{50}$ and $\mathrm{CN}_{100}$ showed a trend of $-3.9 \% \mathrm{yr}^{-1}$ (Fig. 9 , Table 2).

The trends in $\mathrm{CN}$ concentrations are well in agreement with the trend in the daily-mean $\mathrm{CN}_{100}$ concentration in Värriö reported by Asmi et al. (2013). Also, in their study, contrary to Värriö, the $\mathrm{CN}$ trends in Pallas were positive. In Värriö, the $\mathrm{CN}$ concentrations have been decreasing more slowly than the condensation sink (Figs. 8c and 9). Since the $\mathrm{CN}_{50}$ concentration has been decreasing with simultaneous increase in the nucleation mode particle concentration, we may conclude that the particle growth from the nucleation mode to $>50 \mathrm{~nm}$ is not very efficient in Värriö. On the other hand, the decrease in the $\mathrm{CN}_{150}$ has not been as large as the decrease in either $\mathrm{CN}_{50}$ or CS. This suggests that higher biogenic aerosol precursor emissions due to increased temperatures may have accelerated the growth of sub-CCN-sized primary particles to $\mathrm{CCN}$ sizes, partly compensating for the decrease in $\mathrm{SO}_{2}$ and primary particle emissions (Paasonen et al., 2013; see also the discussion in Sect. 3.2.1). One should, however, keep in mind that it is very difficult to separate between the three sources of $\mathrm{CCN}$ based solely on a time series analysis.

\subsection{Association of the observed trends with sulfur emissions from Kola}

Next we will investigate what kinds of trends there are in sulfur dioxide and sulfuric acid concentrations and what their contributions are to the formation and growth of aerosols in Värriö.

\subsubsection{New particle formation vs. sulfur species}

$\mathrm{SO}_{2}$ concentration has been decreasing by $10.9 \% \mathrm{yr}^{-1}$ 1998-2011, while for 1992-2011 the decrease was $5.2 \% \mathrm{yr}^{-1}$ (Fig. 10, Table 2). This decrease was not yet observable in the study made by Ruuskanen et al. (2003) where they used $\mathrm{SO}_{2}$ data from 1992 to 2001 . Likewise, in 


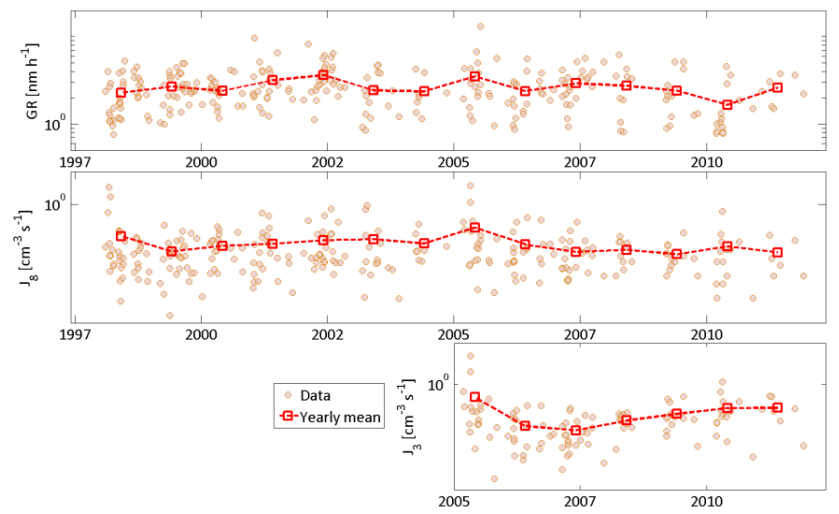

Fig. 7. Growth rate (upper panel) and formation rate of $8 \mathrm{~nm}$ particles (middle panel) 1998-2011 as well as formation rate of $3 \mathrm{~nm}$ particles (lower panel) 2005-2011. The yearly mean values are also shown.

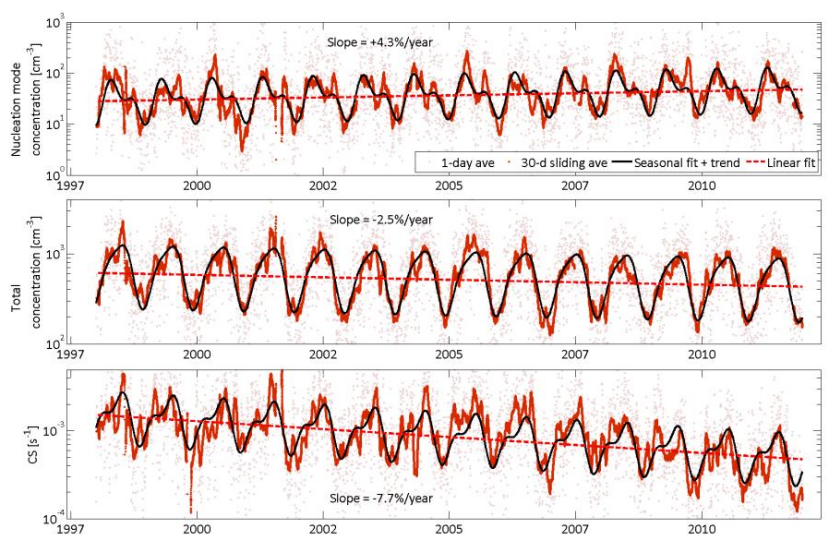

Fig. 8. Trends in nucleation mode and total concentration as well as condensation sink 1998-2011. The light red dots are 1-day averages, the solid dark red line the $30 \mathrm{~d}$ sliding average, the thin black line the sinusoidal seasonal fit with the linear trend added and the red dashed lines the linear fits.

Sevettijärvi, close to Nikel and Zapoliarny smelters, the decrease in $\mathrm{SO}_{2}$ was not very clear in the early 2000s (Virkkula et al., 2003). Sulfuric acid proxy calculated by Eq. (1) on the other hand has been decreasing in Värriö by $5.2 \% \mathrm{yr}^{-1}$ (Fig. 10, Table 2). According to Eq. (1) the lower the condensation sink is, the higher the sulfuric acid concentration is. Since $\mathrm{CS}$ has been decreasing by $7.7 \% \mathrm{yr}^{-1}$, the resulting $\mathrm{H}_{2} \mathrm{SO}_{4}$ concentration without taking into account the $\mathrm{SO}_{2}$ concentration should be increasing. In Värriö, however, the decreasing $\mathrm{SO}_{2}$ counteracts this. On the other hand, the lower the CS is, the longer it takes for vapours to condense on preexisting particles, leading to possible overestimation in sulfuric acid proxy especially if calculated using Eq. (1). In Värriö the vapour lifetime with respect to condensing on particles $\left(\mathrm{CS}^{-1}\right)$ has increased from roughly $20 \mathrm{~min}$ to $1 \mathrm{~h}$; hence it is possible that for the last few years the real sulfuric acid concentration is lower than the calculated value. Compared with

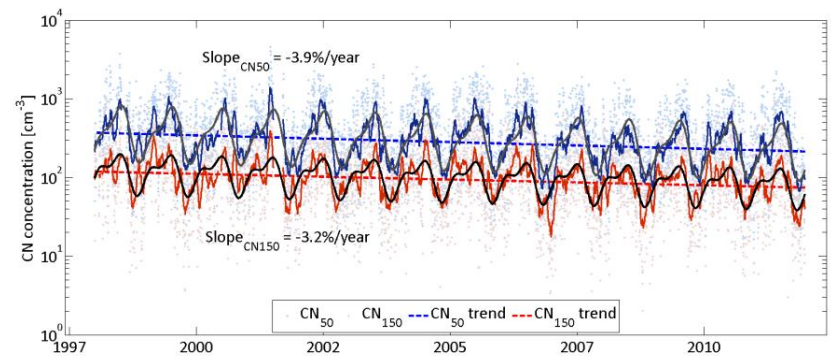

Fig. 9. Same figure as Fig. 9 but for trends in $\mathrm{CN}_{50}$ and $\mathrm{CN}_{150}$ concentrations 1998-2011.

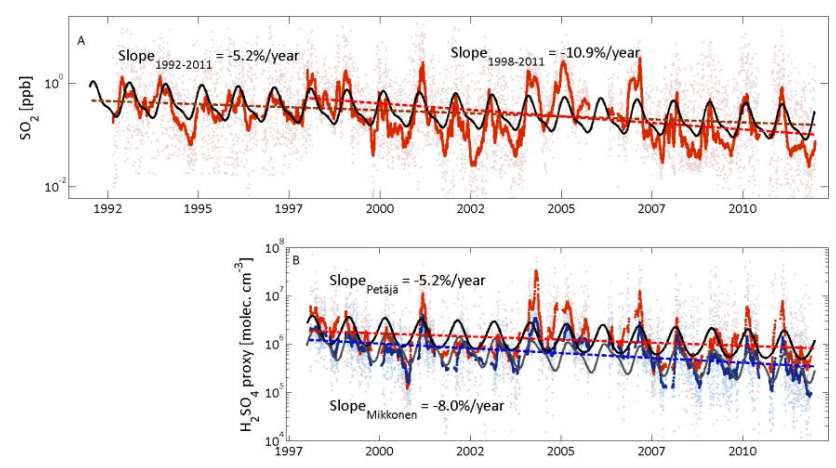

Fig. 10. 1-day averages (dots) and 30-day sliding average (thick line) of $\mathrm{SO}_{2}$ (1992-2011) (A) and $\mathrm{H}_{2} \mathrm{SO}_{4}$ proxy (1998-2011), for proxies Petäjä (red) and Mikkonen (blue) (B), respectively. Sinusoidal seasonal fits with linear trend as well as linear fits to the logarithmic data are shown as well.

Eq. (2), the parameterization by Petäjä et al. (2009) gives slightly higher values during winter-spring when $\mathrm{CS}$ is low (Fig. 4c). Also, the decrease in $\mathrm{H}_{2} \mathrm{SO}_{4}$ proxy is more distinct in the parameterization by Mikkonen et al. (2011) due to weaker dependence on CS $\left(-8.0 \% \mathrm{yr}^{-1}\right)$ (Fig. 10, Table 2).

When we looked at the global radiation as a function of the NPF start time calculated using the apparent GR, HYSPLIT back trajectories (Draxler and Hess, 1998) and $\mathrm{SO}_{2}$ concentration, we saw that higher $\mathrm{SO}_{2}$ concentrations seemed to favour earlier onset of NPF (Fig. 11). This was true especially when the radiation intensity was higher: the difference in NPF start time between times when $\mathrm{SO}_{2}$ was low or high was on average $2-3 \mathrm{~h}$ when the mean global radiation $1 \mathrm{~h}$ before and after the NPF start was higher than $300 \mathrm{~W} \mathrm{~m}^{-2}$ and about an hour when the global radiation was low (Fig. 11). This and the fact that earlier NPF start time after the sunrise is connected to high $\mathrm{SO}_{2}$ concentrations (Fig. 3) clearly show the strong link between $\mathrm{SO}_{2}$ and NPF in Värriö.

In general $\mathrm{H}_{2} \mathrm{SO}_{4}$ explains a large fraction of the growth of the newly formed aerosol $(\sim 20-50 \%)$ (Fig. 12). The percentage is highest in spring (March-May) and autumn (August-September) with minimum in summer. This suggests that in fact at least some fraction of the effects of $\mathrm{SO}_{2}$ and $\mathrm{H}_{2} \mathrm{SO}_{4}$ are related to the early condensational growth 


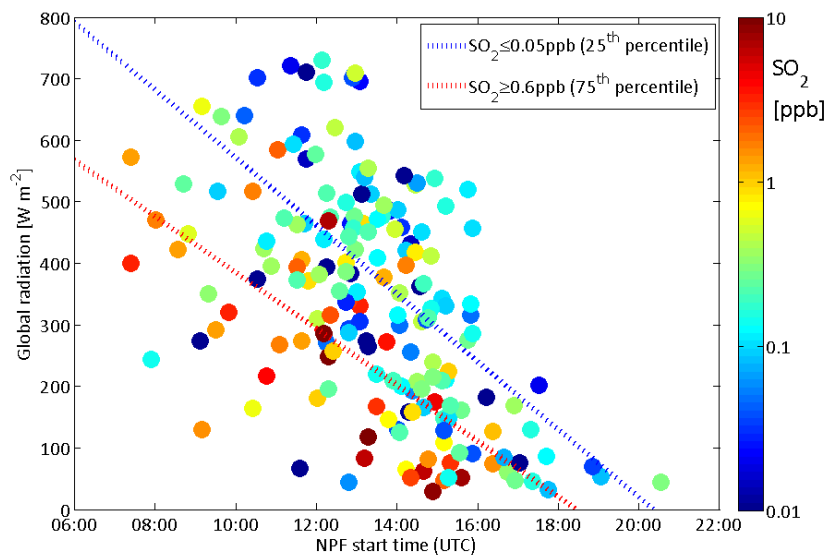

Fig. 11. NPF start time (UTC) as a function of global radiation and sulfur dioxide concentration (colour bar). Both are mean values $1 \mathrm{~h}$ before and after the start of NPF. Linear fits for data when $\mathrm{SO}_{2}$ concentration is less than $0.05 \mathrm{ppb}$ or more than $0.5 \mathrm{ppb}$ are shown with blue and red dashed lines, respectively. These values are the 25 th and 75th percentile of $\mathrm{SO}_{2}$ event-time concentration.

of the particles instead of formation of new particles. Also the $26.2 \% \mathrm{yr}^{-1}$ increase in $J_{3}$ (2006-2011) supports this. Considering that there has been a clear decrease in CS, it seems that during NPF there are not enough vapours for the particles to grow into larger sizes. Both proxies give similar seasonal behaviour, but the parameterization by Petäjä et al. (2009) gives slightly higher percentages (mean $35.8 \%$ ) compared to the parameterization by Mikkonen et al. (2011) (mean $32.6 \%$ ). There is no visible inter-annual trend, although during the last few years the minimum percentage has been increasing. This is most likely due to the change in the event distribution; nearly all of the events from which GR can be calculated were observed during spring in the later period. In Pallas, approximately 5-40\% (Asmi et al., 2011) and in Hyytiälä less than $10 \%$ (Boy, 2005; Fiedler, 2005) of the growth is explained by $\mathrm{H}_{2} \mathrm{SO}_{4}$, which is clearly a much smaller fraction than in Värriö. In addition, the relative importance of $\mathrm{H}_{2} \mathrm{SO}_{4}$ is largest in late winter (February-March) and late summer (August) in Värriö.

The mean spring-summer (April-July) temperatures have increased in Värriö on average $1.3^{\circ} \mathrm{C}\left(+1.9^{\circ} \mathrm{C}\right.$ increase in the median spring temperature) since 1998. Overall, the temperature increase in Värriö has been $0.05 \% \mathrm{yr}^{-1}$ (Table 2), corresponding an increase of $1.2{ }^{\circ} \mathrm{C}$ per decade. This increase in temperature might have increased the emissions of monoterpenes (Paasonen et al., 2013). Since organic vapours are important in the formation and especially growth of new aerosol particles, we would expect to see at least some correlation between the number of NPF events and temperature. Interestingly, during 1998-2011 there was no or very little correlation $\left(R^{2}=0.13\right)$ with class I events and springsummer (April-July) median temperature (and this correlation was negative), but for class II events there was a clear
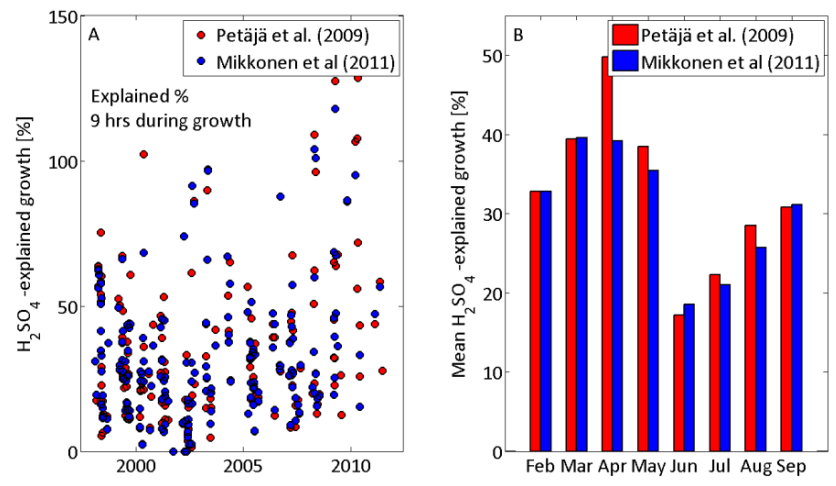

Fig. 12. The time series of the percentage which $\mathrm{H}_{2} \mathrm{SO}_{4}$ explains of the growth (A), its yearly variation (B). Months with fewer than five cases where the percentage has been calculated have been discarded.

positive correlation $\left(R^{2}=0.41\right)$. This supports our hypothesis that an observation of a class II event is connected to organic emissions and not necessarily observed during high concentrations of sulfuric acid originating from Kola since the particles have formed already elsewhere and the importance of sulfuric acid to the early growth has already diminished.

All in all, these results strongly suggest that sulfur dioxide and sulfuric acid have a very important role in NPF in eastern Lapland, especially in the case of clear, undisturbed class I events.

\subsubsection{Connection with Kola emissions}

Some studies have already shown that part of the NPF events observed at Värriö are induced by the high $\mathrm{SO}_{2}$ concentrations associated with air masses coming over Kola (Pirjola et al., 1998; Komppula et al., 2003). All of these studies have however concentrated on a rather limited data set. For example, Komppula (2003) estimated that, during 21 months, roughly one third of the NPF events observed at Värriö were affected or caused by the Kola industry. No studies on the long-term effect of Kola emissions have been made so far.

The highest nucleation mode concentrations occurred when $\mathrm{SO}_{2}$ concentrations were high. When dividing the data into "polluted" ( $\mathrm{SO}_{2} \geq 95$ th percentile) and "clean" $\left(\mathrm{SO}_{2} \leq\right.$ median) data, the yearly sum of $\mathrm{SO}_{2}$ correlated very well with the yearly sum of nucleation mode particle concentration in the polluted data (Fig. 13 left side), whereas for the clean data the correlation was lower (Fig. 13 right side). Also, nearly all of the polluted data originated from the Kola sector, whereas for clean data the winds were mainly from the south-west direction.

One explanation for the decrease in class I events could be boundary layer dynamics during air mass transport from Kola. Usually the wind speed was lower in air masses coming over Kola than in air masses coming from south-west 

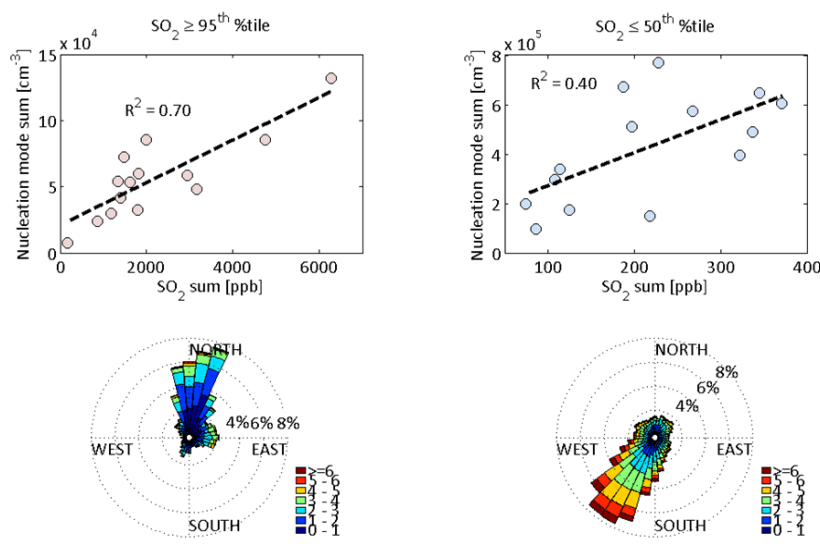

Fig. 13. Yearly sum of nucleation mode particle concentration as a function of yearly sum of $\mathrm{SO}_{2}$ for polluted $\left(\mathrm{SO}_{2}>\right.$ overall 95 th percentile) and clean $\left(\mathrm{SO}_{2}<\right.$ overall median) data and linear fits to them. Corresponding wind roses are plotted below. The colour scale is the wind speed in $\mathrm{m} \mathrm{s}^{-1}$, and the percentages shown in roses are fractions of the all (clean or polluted) data.

(Fig. 13). Since in lower wind speeds the turbulent mixing is reduced, in case of a NPF day this means that there are fewer fluctuations in the air and the event appears smoother and is therefore more probably classified as class I event (Dal Maso et al., 2005; Yli-Juuti et al., 2009).

There was a weak positive correlation between the yearly 95th percentile of $\mathrm{SO}_{2}$ and yearly sum of events (both I and II). The correlation with non-events was much lower, $R^{2}=0.16$.

The majority of the events occurred when the wind direction was south-west. However, when comparing the relative wind direction distribution during event days, undefined days and non-event days, the wind direction was more frequently within the Kola sector $\left(0-95^{\circ}\right)$ during event days and especially during undefined days than during non-event days. In addition to wind direction, we used HYSPLIT back trajectories to investigate the air mass history before arriving at Värriö. These studies showed that air masses came over Kola Peninsula more often on event days than on all days in late winter-early spring, summer and late autumn (Fig. 14). Similar yet much weaker seasonality was also seen when taking into account only the local wind direction. The negative relative differences in winter (Fig. 14) are most likely due to very limited number of NPF events in winter.

The fact that the relative difference (percentage of air masses coming over Kola during event days compared with all days) stays positive nearly throughout the year could be an indication that many class II events originate over Kola, but due to transport times of a few hours to Värriö, we do not see the very formation of new particles in Värriö. Since the emissions from Kola have been decreasing, we expect that the area directly affected by the emissions over the smelters is also decreasing in size. This could explain the reason why
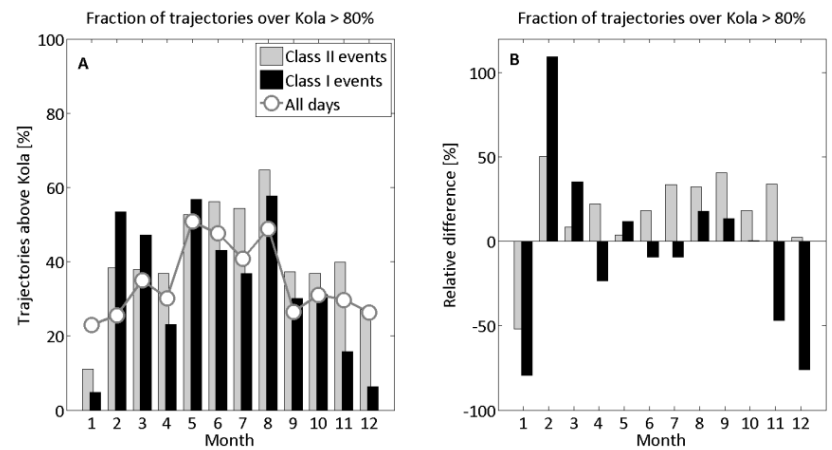

Fig. 14. Fraction of trajectories that come over Kola Peninsula so that the trajectory is over Kola more than $80 \%$ of its time (A), and respective relative differences between NPF days and all days for class I and II events (B). Also the fraction of time when trajectories pass over Kola before arriving at Värriö is shown for all days in (A).

we see the dramatic decrease in class I events, but not in class II events, which are thought to start new particle formation somewhere else than at the site of observation.

\subsubsection{Possible socio-economic reasons for the observed trends}

The main source of anthropogenic atmospheric $\mathrm{SO}_{2}$ in Värriö is the industrial activity in the Murmansk Oblast region. Since the 1990s, the Murmansk region has slid into a socioeconomic decline, which in turn has had an impact on the overall emissions of the region. From 1992 to 2011 the overall amount of atmospheric emissions decreased from 617 thousand to 263.1 thousand tonnes per year (Federal State Statistic Service of Russia, 2013a). In particular, the overall amount of emitted $\mathrm{SO}_{2}$ from stationary sources decreased from 275.8 to $194.6 \mathrm{kT} \mathrm{yr}^{-1}$ for the period from 2000 to 2012. For the period 2001-2012 the amount of $\mathrm{SO}_{2}$ emitted primarily from combustion for energy production (heat and electricity) also declined from 96.3 to $65.8 \mathrm{kT} \mathrm{yr}^{-1}$. The amount of caught and deactivated $\mathrm{SO}_{2}$ emissions from stationary sources has remained the same, being 134.7 and $135.2 \mathrm{kT} \mathrm{yr}^{-1}$ in 2001 and 2012, respectively (Federal State Statistic Service of Russia, 2013b).

Since the amount of deactivated emissions has not changed substantially, whilst the overall emissions have decreased, it is unlikely that this change is due to changes in filtering technology or deactivation methods. Rather, this change can be explained by socio-economic factors, such as changes in the political system, trends in economic development and/or demographic trends.

In the Murmansk Oblast, the regional gross domestic product (RGDP) increased moderately from 55135 to 260264.7 millions of rubble per year from 2000 to 2011 (Federal State Statistic Service of Russia, 2013c). Considering the overall level of inflation, the economy has been in decline, which is also explained by the developments of the sub-sectors of the 
economy. Retrieval of natural resources grew from 18.7 to $18.9 \%$ of RGDP, process manufacturing declined from 21.8 to $15.5 \%$ and production and distribution of energy, gas and water declined from 8.4 to $5.9 \%$ from 2004 to 2011 (Federal State Statistic Service of Russia, 2013d). In addition, demographic trends are an important parameter that explains the reasons for the reduction in emissions. According to the Russian census, population in Murmansk region decreased from 1164586 to 795409 people during the period of 1989-2010 (Federal State Statistic Service of Russia, 2013e).

\section{Conclusions}

We have observed a dramatic decrease in the frequency of class I NPF events in eastern Lapland, Finland, during 14 years of aerosol size distribution measurements. The events have been decreasing throughout the year but especially during summer and autumn. We believe that the decrease in events is due to the gradual disappearance of the extra boost from Kola emissions and that the number of class I events observed in Värriö is now close to the natural background level, similar to that observed in Pallas, western Lapland.

The decreasing anthropogenic $\mathrm{SO}_{2}$ and primary emissions have decreased the CS considerably, leading to an increase in the event time $J_{3}$ and nucleation mode particle concentration. Thus, there are more nucleation mode particles per event. However, since most of the events have been lost during spring and autumn when the importance of sulfuric acid to the growth is the largest, even up to $50 \%$, and the organic emissions from the snow-covered trees especially during spring are minimal, the remaining sulfuric acid vapour concentrations are not high enough for the particles to grow into potential CCN. On the other hand, enhanced secondary organic aerosol formation resulting from increasing temperature is not yet sufficient enough to compensate for this. Hence, the concentrations of apparent $\mathrm{CCN}$ are decreasing.

Events in general start earlier after sunrise during spring due to high concentrations of $\mathrm{SO}_{2}$ and $\mathrm{H}_{2} \mathrm{SO}_{4}$ as well as low CS. We observed also events in total lack of sunlight, and many of them were related to higher than average $\mathrm{SO}_{2}$ concentrations. We also found that high $\mathrm{SO}_{2}$ concentrations can advance the onset of nucleation by several hours especially if there is enough sunlight present.

There are several pieces of evidence showing that the observed decrease in the yearly number of events is connected to the reduction of air pollution from Kola Peninsula smelters. Firstly, when considering only those times when the concentration of $\mathrm{SO}_{2}$ exceeded the 95 th percentile, the yearly sum of $\mathrm{SO}_{2}$ correlated very well with the yearly sum of nucleation mode particle concentration. These data are entirely associated with the Kola sector. For the times when $\mathrm{SO}_{2}$ was lower than the overall median value, the correlation was much lower. Secondly, there was a clear positive correlation between the number of events observed in a given year and the yearly 95th percentile of $\mathrm{SO}_{2}$. Finally, air masses coming over Kola Peninsula seem to favour NPF, especially during late winter, early spring and autumn. The relative difference in air masses coming over Kola on nucleation days compared with all days was several tens of percentages through late winter to autumn, exceeding over $100 \%$ in February in the case of class I events. For class II events the relative difference is positive almost throughout the year. Overall, our results strongly suggest that sulfur species have a very important role in both NPF and subsequent growth and that the recent decrease in Kola sulfur emissions due to socioeconomic changes in the Murmansk Oblast region has had a strong impact on the NPF in eastern Lapland.

In the future, the trends in the NPF in eastern Lapland will likely depend on the overall human activity in the Murmansk Oblast region, the general cleaning of the emissions by new filtering techniques and deactivation methods in there, and changes in natural biogenic emission. Our analysis of the official statistics has shown that the reduction of emissions from stationary sources in the Murmansk Oblast region is more likely to be due to reduction of socio-economic activities in general, rather than due to particular changes in cleaning techniques utilized by industrial establishments. It is very likely that everywhere close to large sources of anthropogenic sulfur emissions with simultaneously low background aerosol concentrations, such as close to Arctic shipping routes, the trends in NPF are governed by these factors. Therefore, due to opening of new shipping routes and increased marine activity, it would be important to conduct more long-term measurements of NPF in the Arctic.

Acknowledgements. The authors wish to express their gratitude for the Academy of Finland Centre of Excellence program (project no. 1118615), European Research Council (project no. 227463ATMNUCLE) and the Nordic Centre of Excellence CRAICC (Cryosphere-atmosphere interactions in a changing Arctic climate) for funding.

Edited by: J. Bäck

\section{References}

Aalto, P., Hämeri, K., Becker, E., Weber, R., Salm, J., Mäkelä, J., Hoell, C., O’Dowd, C. D., Karlsson, H., Hansson, H.-C., Väkevä, M., Koponen, I. K., Buzorius, G., and Kulmala, M.: Physical characterization of aerosol particles during nucleation events, Tellus B, 53, 344-358, 2001.

Asmi, A., Collaud Coen, M., Ogren, J. A., Andrews, E., Sheridan, P., Jefferson, A., Weingartner, E., Baltensperger, U., Bukowiecki, N., Lihavainen, H., Kivekäs, N., Asmi, E., Aalto, P. P., Kulmala, M., Wiedensohler, A., Birmili, W., Hamed, A., O’Dowd, C., G Jennings, S., Weller, R., Flentje, H., Fjaeraa, A. M., Fiebig, M., Myhre, C. L., Hallar, A. G., Swietlicki, E., Kristensson, A., and 
Laj, P.: Aerosol decadal trends - Part 2: In-situ aerosol particle number concentrations at GAW and ACTRIS stations, Atmos. Chem. Phys., 13, 895-916, doi:10.5194/acp-13-895-2013, 2013.

Asmi, E., Kivekäs, N., Kerminen, V.-M., Komppula, M., Hyvärinen, A.-P., Hatakka, J., Viisanen, Y., and Lihavainen, H.: Secondary new particle formation in Northern Finland Pallas site between the years 2000 and 2010, Atmos. Chem. Phys., 11, 12959-12972, doi:10.5194/acp-11-12959-2011, 2011.

Benkovitz, C. M., Scholtz, M. T., Pacyna, J., Tarrasón, L., Dignon, J., Voldner, E. C., Spiro, P. A., Logan, J. A., and Graedel, T. E.: Global gridded inventories of anthropogenic emissions of sulfur and nitrogen, J. Geophys. Res., 101, 29239-29253, 1996.

Berge, E., Bartnicki, J., Olendrzynski, K., and Tsyro, S. G.: Longterm trends in emissions and transboundary transport of acidifying air pollution in Europe, J. Environ. Manage., 57, 31-50, 1999.

Boy, M., Kulmala, M., Ruuskanen, T. M., Pihlatie, M., Reissell, A., Aalto, P. P., Keronen, P., Dal Maso, M., Hellen, H., Hakola, H., Jansson, R., Hanke, M., and Arnold, F.: Sulphuric acid closure and contribution to nucleation mode particle growth, Atmos. Chem. Phys., 5, 863-878, doi:10.5194/acp-5-863-2005, 2005.

Dal Maso, M., Kulmala, M., Riipinen, I., Wagner, R., Hussein, T., Aalto, P. P., and Lehtinen, K. E. J.: Formation and growth of fresh atmospheric aerosols: eight years of aerosol size distribution data from SMEAR II, Hyytiälä, Finland, Boreal Environ. Res., 10, 323-336, 2005.

Dal Maso, M., Sogacheva, L., Aalto, P. P., Riipinen, I., Komppula, M., Tunved, P., Korhonen, L., Suur-Uski, V., Hirsikko, A., Kurtén, T., Kerminen, V.-M., Lihavainen, H., Viisanen, Y., Hansson, H.-C., and Kulmala, M.: Aerosol size distribution measurements at four Nordic field stations: identification, analysis and trajectory analysis of new particle formation bursts, Tellus B, 59, 350-361, 2007.

Draxler, R. R. and Hess, G.: An overview of the HYSPLIT_4 modelling system for trajectories, 25 dispersion, and deposition, Australian Meteorol. Mag., 47, 295-308, 1998.

Ehn, M., Thornton, J. A., Kleist, E., Sipilä, M., Junninen, H., Pullinen, I., Springer, M., Rubach, F., Tillmann, R., Lee, B., LopezHilfiker, F., Andres, S., Acir, I.-H., Rissanen, M., Jokinen, T., Schobesberger, S., Kangasluoma, J., Kontkanen, J., Nieminen, T., Kurtén, T., Nielsen, L. B., Jørgensen, S., Kjaergaard, H. G., Canagaratna, M., Dal Maso, M., Berndt, T., Petäjä, T., Wahner, A., Kerminen, V.-M., Kulmala, M., Worsnop, D. R., and Mentel, T. F.: A large source of low-volatility secondary organic aerosol, Nature, 506, 476-479, doi:10.1038/nature13032, 2014.

Federal State Statistic Service of Russia: Overall emissions data for Murmansk Oblast, available at: http://cbsd.gks.ru/ (last access: 1 September 2013), 2013a.

Federal State Statistic Service of Russia: $\mathrm{SO}_{2}$ Emissions data for Murmansk Oblast, available at: http://cbsd.gks.ru/ (last access: 1 September 2013), 2013b.

Federal State Statistic Service of Russia: Regional gross domestic product for Murmansk Oblast, available at: http://cbsd.gks.ru/ (last access: 1 September 2013), 2013c.

Federal State Statistic Service of Russia: Division of RGDP to subsectors for Murmansk Oblast, available at: http://cbsd.gks.ru/ (last access: 1 September 2013), 2013d.
Federal State Statistic Service of Russia: Population statistics for Murmansk Oblast, available at: http://cbsd.gks.ru/ (last access: 1 September 2013), 2013e.

Fiedler, V., Dal Maso, M., Boy, M., Aufmhoff, H., Hoffmann, J., Schuck, T., Birmili, W., Hanke, M., Uecker, J., Arnold, F., and Kulmala, M.: The contribution of sulphuric acid to atmospheric particle formation and growth: a comparison between boundary layers in Northern and Central Europe, Atmos. Chem. Phys., 5, 1773-1785, doi:10.5194/acp-5-1773-2005, 2005.

Hamed, A., Birmili, W., Joutsensaari, J., Mikkonen, S., Asmi, A., Wehner, B., Spindler, G., Jaatinen, A., Wiedensohler, A., Korhonen, H., Lehtinen, K. E. J., and Laaksonen, A.: Changes in the production rate of secondary aerosol particles in Central Europe in view of decreasing $\mathrm{SO}_{2}$ emissions between 1996 and 2006, Atmos. Chem. Phys., 10, 1071-1091, doi:10.5194/acp-10-10712010, 2010.

Hari, P., Kulmala, M., Pohja, T., Lahti, T., Siivola, E., Palva, L., Aalto, P., Hämeri, K., Vesala, T., Luoma, S., and Pulliainen, E.: Air pollution in eastern Lapland: challenge for an environmetal research station, Silva Fenn., 28, 29-39, 1994.

Hirsikko, A., Laakso, L., Hõrrak, U., Aalto, P. P., Kerminen, V.M., and Kulmala, M.: Annual and size dependent variation of growth rates and ion concentrations in boreal forest, Boreal Environ. Res., 10, 357-369, 2005.

Kendall, M. G.: Rank correlation methods, Griffin London, 202 pp., London, 1975.

Kerminen, V.-M., Lihavainen, H., Komppula, M., Viisanen, Y., and Kulmala, M.: Direct observational evidence linking atmospheric aerosol formation and cloud droplet activation, Geophys. Res. Lett., 32, L14803, doi:10.1029/2005GL023130, 2005.

Kerminen, V.-M., Petäjä, T., Manninen, H. E., Paasonen, P., Nieminen, T., Sipilä, M., Junninen, H., Ehn, M., Gagné, S., Laakso, L., Riipinen, I., Vehkamäki, H., Kurten, T., Ortega, I. K., Dal Maso, M., Brus, D., Hyvärinen, A., Lihavainen, H., Leppä, J., Lehtinen, K. E. J., Mirme, A., Mirme, S., Hõrrak, U., Berndt, T., Stratmann, F., Birmili, W., Wiedensohler, A., Metzger, A., Dommen, J., Baltensperger, U., Kiendler-Scharr, A., Mentel, T. F., Wildt, J., Winkler, P. M., Wagner, P. E., Petzold, A., Minikin, A., Plass-Dülmer, C., Pöschl, U., Laaksonen, A., and Kulmala, M.: Atmospheric nucleation: highlights of the EUCAARI project and future directions, Atmos. Chem. Phys., 10, 10829-10848, doi:10.5194/acp-10-10829-2010, 2010.

Kerminen, V.-M., Paramonov, M., Anttila, T., Riipinen, I., Fountoukis, C., Korhonen, H., Asmi, E., Laakso, L., Lihavainen, H., Swietlicki, E., Svenningsson, B., Asmi, A., Pandis, S. N., Kulmala, M., and Petäjä, T.: Cloud condensation nuclei production associated with atmospheric nucleation: a synthesis based on existing literature and new results, Atmos. Chem. Phys., 12, 1203712059, doi:10.5194/acp-12-12037-2012, 2012.

Komppula, M., Dal Maso, M., Lihavainen, H., Aalto, P. P., Kulmala, M., and Viisanen, Y.: Comparison of new particle formation events at two locations in northern Finland, Boreal Environ. Res., 8, 395-404, 2003.

Komppula, M., Lihavainen, H., Kerminen, V.-M., Kulmala, M., and Viisanen, Y.: Measurements of cloud droplet activation of aerosol particles at a clean subarctic background site, J. Geophys. Res., 110, D06204, doi:10.1029/2004JD005200, 2005.

Kuang, C., Chen, M., Zhao, J., Smith, J., McMurry, P. H., and Wang, J.: Size and time-resolved growth rate measurements of 1 
to $5 \mathrm{~nm}$ freshly formed atmospheric nuclei, Atmos. Chem. Phys., 12, 3573-3589, doi:10.5194/acp-12-3573-2012, 2012.

Kulmala, M., Dal Maso, M., Mäkelä, J. M., Pirjola, L., Väkevä, M., Aalto, P., Miikkulainen, P., Hämeri, K., and O'Dowd C. D.: On the formation, growth and composition of nucleation mode particles, Tellus B, 53, 479-490, doi:10.1034/j.16000889.2001.530411.x, 2001.

Kulmala, M., Vehkamäki, H., Petäjä, T., Dal Maso, M., Lauri, A., Kerminen, V.-M., Birmili, W., and McMurry, P. H.: Formation and growth rates of ultrafine atmospheric particles: a review of observations, J. Aerosol Sci., 35, 143-176, 2004a.

Kulmala, M., Suni, T., Lehtinen, K. E. J., Dal Maso, M., Boy, M., Reissell, A., Rannik, Ü., Aalto, P., Keronen, P., Hakola, H., Bäck, J., Hoffmann, T., Vesala, T., and Hari, P.: A new feedback mechanism linking forests, aerosols, and climate, Atmos. Chem. Phys., 4, 557-562, doi:10.5194/acp-4-557-2004, 2004b.

Kulmala, M., Petäjä, T., Nieminen, T., Sipilä, M., Manninen, H. E., Lehtipalo, K., Dal Maso, M., Aalto P. P., Junninen, H., Paasonen, P., Riipinen, I., Lehtinen, K. E. J., Laaksonen, A., and Kerminen, V.-M.: Measurement of the nucleation of atmospheric aerosol particles, Nat. Protoc., 7, 1651-1667, 2012.

Kulmala, M., Kontkanen, J., Junninen, H., Lehtipalo, K., Manninen, H. E., Nieminen, T., Petäjä, T., Sipilä, M., Schobesberger, S., Rantala, P., Franchin, A., Jokinen, T., Järvinen, E., Äijälä, M., Kangasluoma, J., Hakala, J., Aalto, P. P., Paasonen, P., Mikkilä, J., Vanhanen, J., Aalto, J., Hakola, H., Makkonen, U., Ruuskanen, T., Mauldin III, R. L., Duplissy, J., Vehkamäki, H., Bäck, J., Kortelainen, A., Riipinen, I., Kurtén, T., Johnston, M. V., Smith, J. N., Ehn, M., Mentel, T. F., Lehtinen, K. E. J., Laaksonen, A., Kerminen, V.-M., and Worsnop, D. R.: Direct Observations of Atmospheric Aerosol Nucleation, Science, 22, 943-946, doi:101126/science.1227385, 2013.

Kupiainen, K. and Klimont. Z.: Primary emissions of fine carbonaceous particles in Europe, Atmos. Environ., 41, 2156-2170, 2006.

Liepert, B. and Tegen, I.: Multidecadal solar radiation trends in the United States and Germany and direct tropospheric aerosol forcing, J. Geophys. Res., 107, 4153, doi:10.1029/2001JD000760, 2002.

Makkonen, R., Asmi, A., Kerminen, V.-M., Boy, M., Arneth, A., Guenther, A., and Kulmala, M.: BVOC-aerosol-climate interactions in the global aerosol-climate model ECHAM5.5-HAM2, Atmos. Chem. Phys., 12, 10077-10096, doi:10.5194/acp-1210077-2012, 2012.

Mann, H. B.: Nonparametric tests against trend, Econometrica, 13, 245-259, 1945.

MathWorks, Inc.: Matlab user manual for R2010a, 2010.

Mikkonen, S., Romakkaniemi, S., Smith, J. N., Korhonen, H., Petäjä, T., Plass-Duelmer, C., Boy, M., McMurry, P. H., Lehtinen, K. E. J., Joutsensaari, J., Hamed, A., Mauldin III, R. L., Birmili, W., Spindler, G., Arnold, F., Kulmala, M., and Laaksonen, A.: A statistical proxy for sulphuric acid concentration, Atmos. Chem. Phys., 11, 11319-11334, doi:10.5194/acp-11-11319-2011, 2011.

Nieminen, T., Asmi, A., Dal Maso, M., P. Aalto, P., Keronen, P., Petäjä, T., Kulmala, M., and Kerminen, V.-M.: Trends in atmospheric new-particle formation: 16 years of observations in boreal forest environment, Boreal Environ. Res., 19 (suppl. B), in press, 2014.
Paasonen, P., Nieminen, T., Asmi, E., Manninen, H. E., Petäjä, T., Plass-Dülmer, C., Flentje, H., Birmili, W., Wiedensohler, A., Hõrrak, U., Metzger, A., Hamed, A., Laaksonen, A., Facchini, M. C., Kerminen, V.-M., and Kulmala, M.: On the roles of sulphuric acid and low-volatility organic vapours in the initial steps of atmospheric new particle formation, Atmos. Chem. Phys., 10, 11223-11242, doi:10.5194/acp-10-11223-2010, 2010.

Paasonen, P., Asmi, A., Petäjä, T., Kajos, M. K., Äijälä, M., Junninen, H., Holst, T., Abbatt, J. P. D., Arneth, A., Birmili, W., Denier vand der Gon, H., Hamed, A., Hoffer, A., Laakso, L., Laaksonen, A., Leaitch, W. R., Plass-Dülmer, C., Pryor, S. C., Räisänen, P., Swietlicki, E., Wiedensohler, A., Worsnop, D. R., Kerminen, V.-M., and Kulmala, M.: Warming-induced increase in aerosol number concentration likely to moderate climate change, Nat. Geosci., 6, 438-442, doi:10.1038/NGEO1800, 2013.

Paatero, J., Dauvalter, V., Derome, J., Lehto, J., Pasanen, J., Vesala, T., Miettinen, J., Makkonen, U., Kyrö, E.-M., Jernström, J., Isaeva, L., and Derome, K.: Effects of Kola air pollution on the environment in the western part of the Kola peninsula and Finnish Laplad: final report, Finnish Meteorological Institute Reports, 6, 1-26, 2008.

Petäjä, T., Mauldin, III, R. L., Kosciuch, E., McGrath, J., Nieminen, T., Paasonen, P., Boy, M., Adamov, A., Kotiaho, T., and Kulmala, M.: Sulfuric acid and $\mathrm{OH}$ concentrations in a boreal forest site, Atmos. Chem. Phys., 9, 7435-7448, doi:10.5194/acp9-7435-2009, 2009.

Pierce, J. R. and Adams, P. J.: Uncertainty in global CCN concentrations from uncertain aerosol nucleation and primary emission rates, Atmos. Chem. Phys., 9, 1339-1356, doi:10.5194/acp-91339-2009, 2009.

Pirjola, L., Laaksonen, A., Aalto, P., and Kulmala, M.: Sulfate aerosol formation in the Arctic boundary layer, J. Geophys. Res. 103, 8309-8321, 1998.

Prank, M., Sofiev, M., Denier van der Gon, H. A. C., Kaasik, M., Ruuskanen, T. M., and Kukkonen, J.: A refinement of the emission data for Kola Peninsula based on inverse dispersion modelling, Atmos. Chem. Phys., 10, 10849-10865, doi:10.5194/acp10-10849-2010, 2010.

Riccobono, F., Rondo, L., Sipilä, M., Barmet, P., Curtius, J., Dommen, J., Ehn, M., Ehrhart, S., Kulmala, M., Kürten, A., Mikkilä, J., Paasonen, P., Petäjä, T., Weingartner, E., and Baltensperger, U.: Contribution of sulfuric acid and oxidized organic compounds to particle formation and growth, Atmos. Chem. Phys., 12, 9427-9439, doi:10.5194/acp-12-9427-2012, 2012.

Riipinen, I., Yli-Juuti, T., Pierce, J. R., Petäjä, T., Worsnop, D. R., Kulmala, M., and Donahue, N. M.: The contribution of organics to atmospheric nanoparticle growth, Nat. Geosci., 5, 453-458, doi:10.1038/ngeo1499, 2012.

Ruuskanen, T., Reissell, A., Keronen, P., Aalto, P. P., Laakso, L., Grönholm, T., Hari, P., and Kulmala, M.: Atmospheric trace gas and aerosol particle concentration measurements in Eastern Lapland, Finland, 1992-2001, Boreal Eviron. Res., 8, 335-349, 2003.

Sihto, S.-L., Mikkilä, J., Vanhanen, J., Ehn, M., Liao, L., Lehtipalo, K., Aalto, P. P., Duplissy, J., Petäjä, T., Kerminen, V.-M., Boy, M., and Kulmala, M.: Seasonal variation of CCN concentrations and aerosol activation properties in boreal forest, Atmos. Chem. Phys., 11, 13269-13285, doi:10.5194/acp-11-13269-2011, 2011. 
Sipilä, M., Berndt, T., Petäjä, T., Brus, D., Vanhanen, J., Sratmann, F., Patokoski, J., Mauldin, R. L., III, Hyvärinen, A.P., Lihavainen, H., and Kulmala, M.: The Role of Sulfuric Acid in Atmospheric Nucleation, Science, 327, 1243-1246, doi:10.1126/science.1180315, 2010.

Smith, S. J., van Aardenne, J., Klimont, Z., Andres, R. J., Volke, A., and Delgado Arias, S.: Anthropogenic sulfur dioxide emissions: 1850-2005, Atmos. Chem. Phys., 11, 1101-1116, doi:10.5194/acp-11-1101-2011, 2011.

Tunved, P., Hansson, H.-C., Kerminen, V.-M., Ström, J., Dal Maso, M., Lihavainen, H., Viisanen, Y., Aalto, P. P., Komppula, M., and Kulmala, M.: High Natural Aerosol Loading over Boreal Forests, Science, 312, 261-263, doi:10.1126/science.1123052, 2006.

Vehkamäki, H., Dal Maso, M., Hussein, T., Flanagan, R., Hyvärinen, A., Lauros, J., Merikanto, P., Mönkkönen, M., Pihlatie, K., Salminen, K., Sogacheva, L., Thum, T., Ruuskanen, T. M., Keronen, P., Aalto, P. P., Hari, P., Lehtinen, K. E. J., Rannik, Ü., and Kulmala, M.: Atmospheric particle formation events at Värriö measurement station in Finnish Lapland 1998-2002, Atmos. Chem. Phys., 4, 2015-2023, doi:10.5194/acp-4-2015-2004, 2004.
Vestreng, V., Myhre, G., Fagerli, H., Reis, S., and Tarrasón, L.: Twenty-five years of continuous sulphur dioxide emission reduction in Europe, Atmos. Chem. Phys., 7, 3663-3681, doi:10.5194/acp-7-3663-2007, 2007.

Virkkula, A., Teinilä, K., Hillamo, R., and Stohl, A.: A decade of trace gas measurements using DOAS in Finnish Lapland, Boreal Environ. Res., 8, 351-363, 2003.

Yli-Juuti, T., Riipinen, I., Aalto, P. P., Nieminen, T., Maenhaut, W., Janssens, I. A., Claeys, M., Salma, I., Ocskay, R., Hoffer, A., Imre, K., and Kulmala, M.: Characteristics of new particle formation events and cluster ions at K-puszta, Hungary, Boreal Environ. Res., 14, 683-698, 2009.

Yli-Juuti, T., Nieminen, T., Hirsikko, A., Aalto, P. P., Asmi, E., Hõrrak, U., Manninen, H. E., Patokoski, J., Dal Maso, M., Petäjä, T., Rinne, J., Kulmala, M., and Riipinen, I.: Growth rates of nucleation mode particles in Hyytiälä during 20032009: variation with particle size, season, data analysis method and ambient conditions, Atmos. Chem. Phys., 11, 12865-12886, doi:10.5194/acp-11-12865-2011, 2011. 